\title{
The Problem of Truth, Happiness and Self-Refutation in the Philosophical Viewpoint of the World by Pyrrho of Elis
}

\author{
Problém pravdy, blaženosti a sebavyvrátenia \\ vo filozofickom pohl'ade na svet u Pyrrhóna z Elidy
}

Andrej Kalaš

\begin{abstract}
This paper attempts to explore the concept of truth, human happiness and the related problem of self-refutation in the philosophical viewpoint of the world by Pyrrho of Elis. I argue that according to the so-called metaphysical interpretation of Pyrrho, the reason for our radical incompetence when it comes to knowledge is not our cognitive inability to grasp the truth, but rather the very nature of things of the world. I provide an alternative philosophical interpretation which is based on a philological conjecture in the preserved textual source. I then point out a surprising connection between this radical attitude and the achievement of human happiness, which constitutes the ultimate goal of Pyrrho's philosophy. Finally, I present a possible solution to the problem of self-refutation, which is in a sense a challenge for radical Pyrrhonian agnosticism. By this paper, I endeavour to show how bizarre could be the image of the world viewed by the prism of radical skepticism of the early Pyrrhonism. Nevertheless, it is a world, wherein the philosopher vindicates his/her eudaimonia and defends the logical consistency of one's own claims.
\end{abstract}

This publication was made possible through the support of the grant project APVV-18-0103 Paradigmatic changes in the understanding of Universe and Man from philosophical, theological, and physical perspectives. 


\title{
Keywords
}

Pyrrho of Elis - ancient skepticism - the nature of things of the world - truth - happiness self-refutation

\begin{abstract}
Abstrakt
Štúdia sa snaží vysvetlit' pojem pravdy, l'udského štastia, a súvisiaci problém sebavyvrátenia vo filozofickom pohl'ade na svet u Pyrrhóna z Elidy. Snažíme sa dokázat', že v duchu tzv. metafyzickej interpretácie tohto filozofa dôvodom našej totálnej poznávacej inkompetencie nie je neschopnost' našich kognitívnych mohutností uchopit' pravdu, ale sama povaha vecí sveta. Naznačujeme alternatívnu filozofickú interpretáciu, ktorá sa zakladá na filologickej konjektúre zachovaného textu. Následne poukazujeme na prekvapivé prepojenie medzi týmto radikálnym skeptickým postojom a dosahovaním l'udskej blaženosti, ktorá konštituuje posledný ciel' Pyrrhónovej filozofie. Napokon predstavujeme pozitívne riešenie problému sebavyvrátenia, ktoré je $v$ istom zmysle oslabením radikálneho Pyrrhónovho agnosticizmu. Predkladanou štúdiou sa snažíme ukázat', aký bizarný môže byt' obraz sveta nazeraného cez prizmu radikálneho skepticizmu raného pyrrhonizmu. Napriek tomu je to svet, v ktorom filozof zdôvodňuje svoju blaženost' a bráni logickú konzistentnost' vlastných tvrdení.
\end{abstract}

\section{Kl'účové slová}

Pyrrhón z Elidy - antický skepticizmus - povaha vecí sveta - pravda - štastie - sebavyvrátenie.

The present study ${ }^{1}$ is an attempt to depict the notion of truth, happiness and self-refutation in Pyrrho of Elis (365-275 BC). Pyrrho was the first important Hellenistic skeptic philosopher, who lived at the turn of the Classical and Hellenistic periods of Greek philosophy. Despite the fact that he did not write any philosophical treatises, he gained many admirers and followers. ${ }^{2}$

1 The paper offers a significantly elaborated version of the sketches I presented at the conference Truth: Theoretical and Practical Aspects, organized by the Slovak Philosophical Association in Smolenice on October 18-20, 2017. For invaluable remarks and comments, I owe special thanks to Ulrich Wollner. This paper also brings together many scattered and isolated findings presented in a number of my previous publications, especially in my monograph on Pyrrho (KALAŠ, A. Pyrrhón z Élidy...). Nevertheless, the added value of the text is not merely my novel rearrangement of the data but, in particular, my proposal in the final chapter of an elegant and inventive explanation of how to save Pyrrho from selfrefutation.

2 A testimony on the absence of Pyrrho's writings can be found in Aristocles, preserved by Eusebius: "Pyrrho came across the books of Democritus, he neither found anything useful there nor wrote anything good himself, but spoke evil of all, both gods and men" (Aris- 
The later neo-Pyrrhonian skeptic school was named after him. However, taking into account historical authenticity, this denomination cannot be correct. It is even outright misleading, since these philosophers called themselves of

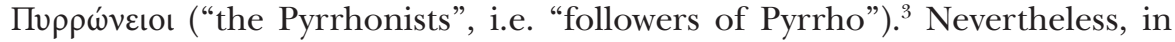
comparison with this "Pyrrhonian tradition", Pyrrho's own philosophy was much more radical. To make Pyrrho's philosophy usable in relation to their goals, the ancient "Pyrrhonists" had to alter it significantly. Pyrrho served more as an ideological trademark for these philosophers. They borrowed from the monumental authority of the skeptic sage, who - as W. Görler succinctly put it - gave to later skepticism nothing but its name. ${ }^{4}$ Considering the doctrinal discontinuity between Pyrrho and his Hellenistic followers, the

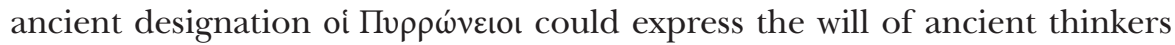
to pay respect to and join the tradition represented - on the neo-Pyrrhonian view - by the majestic personality of Pyrrho of Elis. It is precisely in terms of the issue of truth, which is the first topic of this study that Pyrrho significantly differs not only from neo-Pyrrhonism but also from a major part of the Greek philosophical tradition. His answer to the problem of happiness is equally atypical in the Greek context, resembling the nirvana of the Eastern

tocles apud Eusebium, Praep. evang. XIV,18,27,3-5, fr. 23 Caizzi). The fact that Pyrrho did not write at all but nonetheless exercised an epochal influence on his followers and a whole generation of philosophers has prompted scholars to draw a parallel between him and Socrates. A. A. Long, for instance, writes that among the Hellenistic philosophers, Pyrrho played a role which is in many ways comparable to that of Socrates in the philosophical context of the $4^{\text {th }}$ century BC (LONG, A. - SEDLEY, D. The Hellenistic Philosophers I..., p. 16).

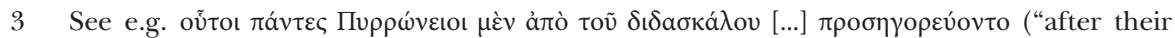
teacher, all of these men were called Pyrrhonists"; Diogenes Laertius, Vitae 9, 69, 12); cf. Sextus Empiricus, Pyrrh. hyp. 1,232,2-3; 1,7,6-7.

4 GÖRLER, W. Pyrrhon aus Elis..., p. 732. The alternative point of view is represented by scholars who tend to minimize or completely deny the differences between the early Pyrrhonism of Pyrrho himself and neo-Pyrrhonism, e.g. BECKWITH, CH. Greek Buddha..., p. 20; STOPPER, M. Schizzi...; SVAVARSSON, S. Pyrrho's..., pp. 280 ff.; STOUGH, CH. Greek Scepticism..., pp. 16-34; ANNAS, J. The Morality..., pp. 204-205 and KUZMINSKI, A. Pyrrhonism and the Madhyamaka..., pp. 485-486. Similarly, Horyna's popularizing philosophical account of Pyrrho (HORYNA, B. Filosofie skepse..., pp. 28-31), besides other drawbacks (the absence of exact quotations, generalizations about the whole of Greek skepticism (ibidem, pp. $37 \mathrm{ff}$ ), suffers from the erroneous attribution to Pyrrho of a complex of mostly neo-Pyrrhonian positions. Although interesting, Horyna's elaborations on the concept of truth in ancient skepticism (ibidem, pp. 53-56) have no relevance for my paper, because they draw ahistorically from reproduced thoughts reported in Sextus Empiricus' writings. 
sages more than the eudaimonia of the Greek philosophers. ${ }^{5}$ Finally, in the third part of the paper, I will show that the core of Pyrrho's philosophy can be interpreted as a religious tenet - a viewpoint that is radically different from that of the argument-based skepticism of the neo-Pyrrhonists.

\section{Truth}

When Pyrrho appeared on the scene of Greek thought, epistemology underwent a significant turn. Not only was the theory of knowledge concerned with the nature of knowing, the transfer mechanism of sensations and the emergence of rational knowledge, but it was tasked with justifying the very existence of knowledge itself. Brunschwig says that with Pyrrho, and after Aristotle's death, "philosophy saw itself driven from a happy paradise of epistemological innocence". ${ }^{6}$ An explicit confirmation of this can be found in the opening words of Aristocles' account of Pyrrho, where he says that the first subject of inquiry is our capacity or incapacity to know anything at all. This primary moment of examination determines, according to the doxographer, the entire course of our philosophical endeavors. ${ }^{7}$ The key testimony for unveiling Pyrrho's attitude toward truth is Aristocles' text, contained in a fragment from Eusebius, which figures as fragment 53 of Caizzi's

5 The hypothesis that Eastern thought influenced Pyrrho is the basis of the so-called Orientalizing interpretation of Pyrrho. I will not follow this lead in this paper, however. As early as the $19^{\text {th }}$ century, this interpretation was embraced by Brochard (BROCHARD, V. Les Sceptiques..., p. 53) and Campbell (CAMPBELL, L. V. Brochard, Les Sceptiques..., p. 112). As for more recent authors, see Frenkian (FRENKIAN, A. Scepticismul grec...); FLINTOFF, E. Pyrrho..., pp. 88-108; KALAŠ, A. Pyrrhón z Élidy..., 46-50; BECKWITH, CH. Greek Buddha...). The latter authors adduce solid conclusions about early Buddhist influences on Pyrrho. I sympathize with these proposals, agreeing strongly with the argumentation that Pyrrho must have visited India with Alexander's army at a very young age, in his early twenties (BECKWITH, CH. Greek Buddha..., pp. 13-14). A. Kuzminski's monograph (KUZMINSKI, A. Pyrrhonism: how the ancient Greeks...) offers a systematic comparison of later Pyrrhonism and the doctrine of later normative Buddhism (the so-called Madhyamaka School). Although the influence of Eastern wisdom on Pyrrho is Kuzminski's fundamental premise, readers of his lengthy book are likely to be bewildered by the fact that for him, the thought of Pyrrho of Elis and the skepticism of the neo-Pyrrhonian school are one and the same.

6 BRUNSCHWIG, J. Introduction..., p. 229.

7 "Before all things it is necessary to make a thorough examination of our own knowledge; for if it is our nature to know nothing there is no further need to inquire about other things" (Aristocles apud Eusebium, Praep. evang. XIV,18,1,1-2,1, fr. 53 Caizzi). 
collection. Although the fragment has had quite a complicated history in the doxographic tradition, passing through as many as three intermediaries, ${ }^{8}$ it remains a crucial source of our information on Pyrrho's philosophy. ${ }^{9}$ It contains three philosophical questions, answered one after another, which must be correctly solved by anyone who wants to live a happy live: What is the nature of things? In what way should we be disposed towards them? And what advantage will there be for those who are so disposed? ${ }^{10}$ If we are to determine Pyrrho's notion of truth, the answers to the first two questions will be important for us:

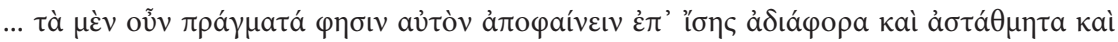

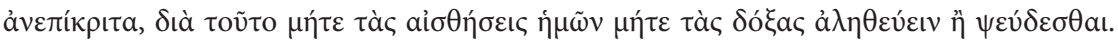

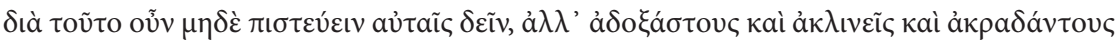
عĩval...

... concerning the things themselves, as he [Timon] says, he [Pyrrho] declares, that they are equally indifferentiable and unmeasurable and undecidable, and therefore neither our perceptions nor our beliefs are either true or false. For this reason then we must not trust them, but we must be without opinions, and without inclinations, and without wavering... ${ }^{11}$

In order to understand logic of Pyrrho's thought, it is important to see that the answer to the first question (What is the nature of things?) is a logical ground for the assertion that answers the second problem (In what way should we be disposed towards them?). In the original ancient Greek text, this logical

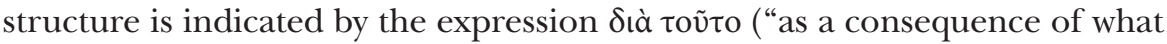

8 For a detailed account see KALAŠ, A. Pyrrhón z Élidy..., pp. 104-111.

9 The authenticity of Timon's information about Pyrrho in Aristocles' version, reported by the Church Father Eusebius, is defended by I. Ch. Beckwith (BECKWITH, CH. Greek Buddha..., p. 17, n. 61). On the other hand, it is questioned by A. Kuzminski, who, in disagreement with R. Bett, argues that the peripatetic philosopher Aristocles, as a dogmatist, could not understand the philosophy of Pyrrho adequately (KUZMINSKI, A. Pyrrhonism and the Madhyamaka..., pp. 484-485). In any case, it is obvious that Kuzminski's unwillingness to admit the historical authenticity of Aristocles' testimony on Pyrrho is simply a byproduct of his identification of Pyrrho with neo-Pyrrhonism (see footnotes 3 and 4).

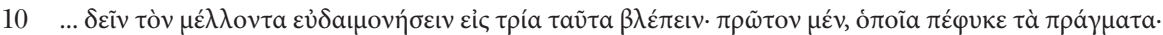

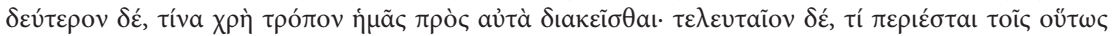

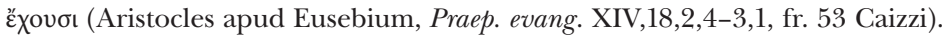

11 Aristocles apud Eusebium, Praep. evang. XIV,18,3,1-3,5, fr. 53 Caizzi. Here, I am following Svavarsson's translation of the Greek text, with modifications (cf. SVAVARSSON, S. Pyrrho's..., p. 269). 
was stated before..."), which implies a relation of consequence. ${ }^{12}$ It means that what precedes is a cause or a logical reason for what follows. What, then, is Pyrrho's conception of truth? The philosopher gives us a surprising answer. He does not claim that this truth is hidden, unreachable or even

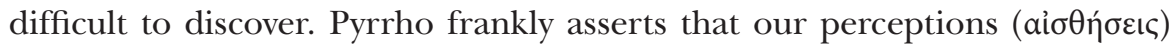
and beliefs ("and opinions" - $\delta o ́ \xi \alpha \iota)$ are beyond true and false, do not report truthfully, but also do not lie. Why? The answer is given in the previous claim about the nature of things. Things in the world are, according to Pyrrho,

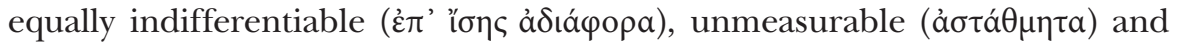

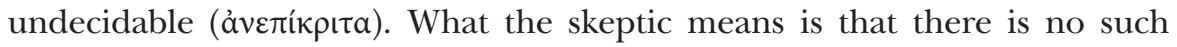
thing as truth because the nature of things is such that it simply does not allow for the categories of "true" and "false", nor for the true/false distinction. This manuscriptal reading of the text reported by Eusebius, i.e. the rejection

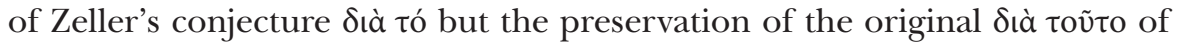
the manuscripts, is the basis of the so-called metaphysical interpretation of Pyrrho, which is upheld by several commentators. ${ }^{13}$

Quite different consequences follow from accepting Zeller's conjecture. According to this author and his text-critical proposal, the course of reasoning would be reversed: what follows is a logical reason for what precedes. The consequences of Zeller's approach support the so-called epistemological interpretation of Pyrrho. The reason for this interpretation is offered in the following section of Pyrrho's text, emended by Zeller:

... concerning the things themselves, as he [Timon] says, he [Pyrrho] declares, that they are equally indifferentiable and unmeasurable and undecidable, and it

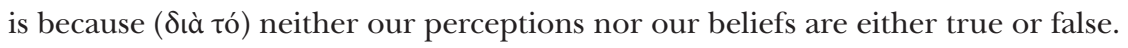

12 For this original ancient Greek version, E. Zeller (ZELLER, E. Die Philosophie..., pp. 494506) suggests the conjecture $\delta$ ı̀ tó ("because of", "since"). It is worth mentioning that the

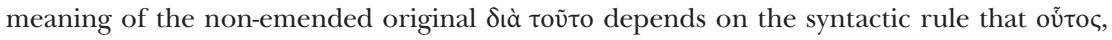

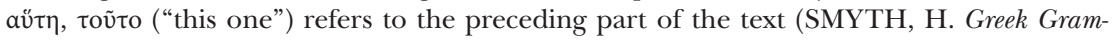
mar..., § 1245). Those scholars who accept Zeller's conjecture favor the so-called epistemological interpretation of Pyrrho: e.g. M. R. Stopper (STOPPER, M. Schizzi..., pp. 292-293, n. 53); J. Annas (ANNAS, J. The Morality..., p. 203) and T. Brennan (Brennan, T. Pyrrho..., pp. 432-433). The epistemological interpretation will be treated below.

13 E.g. F. Decleva Caizzi (CAIZZI, D. Pirrone..., pp. 226-227); R. Bett (BETT, R. Pyrrho, His Antecedents..., p. 19). A comprehensive list of scholarly authorities who uphold the metaphysical interpretation can be found in the study by S. H. Svavarsson (SVAVARSSON, S. Pyrrho's..., p. 271, n. 34). 
For this reason then we must not trust them, but we must be without opinions, and without inclinations, and without wavering... ${ }^{14}$

In this view, our own cognitive incapacity is the primary reason for the fact

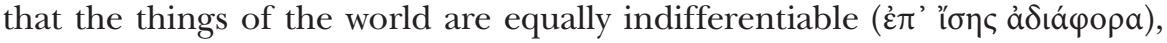

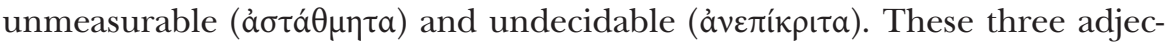
tives, which characterize the nature of things on the grounds of epistemological interpretation, cannot be understood "ontologically", but only in an epistemological sense: things are indifferentiable "for us", unmeasurable for our measuring tools and undecidable by means of our intellect. ${ }^{15}$

The principal argument in favor of the metaphysical interpretation is this: If we can explain Pyrrho's philosophy consistently without philological emendation, the latter is redundant. If the decision to follow the metaphysical interpretation among several others ${ }^{16}$ is correct, and if we take the non-emended Greek text of fragment 53 Caizzi to be historically plausible, Pyrrho appears to be a very radical philosopher, not only with regard to his concept of truth. Can we even imagine what consequences follow from his radical position on the nature of things? Answering the third question of Aristocles' fragment from Eusebius (What advantage will there be for those who are so disposed?), Pyrrho promises the best that anyone can wish for. Those who are so disposed, according to Pyrrho's recommendations, will be given

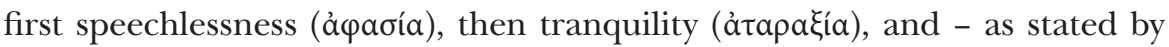

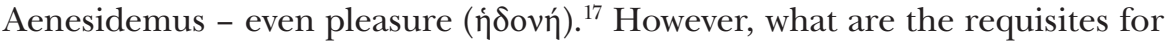
such a blissful condition? Pyrrho requests one thing only, namely, that one

14 Aristocles apud Eusebium, Praep. evang. XIV,18,3,1-3,5, fr. 53 Caizzi.

15 There is a special group of authors who, on the one hand, do not accept Zeller's conjecture, which means that they - as it were - maintain a sort of metaphysical interpretation but, on the other hand, put the stress on the subjective, epistemological aspect of Pyrrho's conception of things (STOUGH, CH. Greek Scepticism..., pp. 17-19; Long, A. Hellenistic Philosophy..., pp. 81-82). This stance is unacceptable, however, because there is no midpoint between these two extreme positions: either there is no truth about things, and then any epistemology loses its ground, or there is a truth about things, but our epistemological capacities are completely unable to grasp it.

16 An inquisitive reader can find as many as eight possible interpretation of Pyrrho in KALAŠ, A. Pyrrhón z Élidy..., p. 8. Among them, the most serious pretenders to historical plausibility remain the metaphysical, the epistemological, the ethical and the phenomenalistic interpretations (for a comparison between them and on the advantages of the first, see KALA $\breve{S}$, A. Pyrrhón z Élidy..., p. 126).

17 Aristocles apud Eusebium, Praep. evang. XIV,18,4,2-4,3, fr. 53 Caizzi. 
make, in every possible circumstance, of every possible thing, the following sublime assertion:

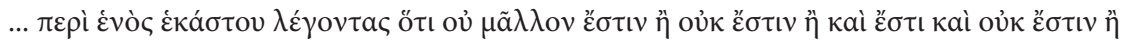

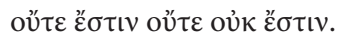

We should say of every single thing that it no more is than is not, that it no more is than both is and is not, that it no more is then neither is nor is not. ${ }^{18}$

It would go beyond the constraints of this paper to provide a detailed commentary on this "magical" formula, or - as it were - this quasi "mantra" of Pyrrhonian skepticism. ${ }^{19}$ Generally, there are three possible ways to translate, and consequently three possible philosophical interpretations of, the text. In any case, all of them confirm Pyrrho's conviction concerning the fundamentally indefinite (unknowable) nature of things. ${ }^{20}$ But how can we reconcile any assertion - even of this skeptical mantra - with the radical epistemological agnosticism based on a metaphysical belief in the agnostic nature of things themselves? If Pyrrho is unconditionally convinced about the radical unknowability of the world, if he is, with regard to this very belief about the world, a "dogmatist", ${ }^{21}$ why does he command us to say something

18 Ibidem, XIV,18,3,5-4,1 (my translation).

19 In the syntactic structure of Pyrrho's dictum, certain scholars detect a form often used by Indian philosophers, the so-called quadrilemma. In describing certain problems, the Indian sages endeavored to show, in four consecutive steps, that they were unsolvable (see FLINTOFF, E. Pyrrho..., p. 93; BRUNSCHWIG, J. Introduction..., p. 244). However, R. J. Hankinson (HANKINSON, R. The Sceptics..., pp. 64-65), a keen adversary of the Orientalizing interpretation, argued against the hypothetical influence of Indian quadrilemma on Pyrrho's thought. His polemic dispute with J. Brunschwig was critically reviewed by A. Kalaš (KALAŠ, A. Pyrrhón z Élidy..., pp. 100-103).

20 As I argue elsewhere (KALAŠ, A. Pyrrhón z Élidy..., pp. 77-86), no epistemological value, according to Pyrrho, can be attributed to a simple assertion ("is") or to its negation ("is not"), or to a composite assertion ("both is and is not") or to its negation ("neither is nor is not").

21 Pyrrho's radical conviction about the unknowability of the world led several modern (and perhaps even ancient) authors to consider him a "dogmatist", or, to be more exact, a "negative dogmatist" (in the literature, we also find the expressions "skeptical dogmatist" and "dogmatic skeptic"), i.e. someone who held dogmatic beliefs about the unknowability of the world. Proving this thesis, and stressing the difference between Pyrrho and the neo-Pyrrhonists, who were the typical ancient "non-dogmatists", is the aim of the crucial chapter in R. Bett's book Pyrrho the Non-Sceptic (BETT, R. Pyrrho, His Antecedents..., pp. 14-62). Pyrrho's dogmatism in ethics is pointed out by those scholars who consider him a chiefly ethical thinker who never dealt seriously either with epistemology or with other philosophical 
about every single thing around us? If our knowledge is fundamentally impossible because of the unknowable nature of things, why should we say anything at all about these things - even the fact that they are unknowable? Isn't Pyrrho contradicting himself? Does he not refute himself if, on the one hand, he forbids something and, on the other hand, he commands us to do something? Let us postpone for the moment this serious issue of self-refutation, which has confounded more than a few skeptics, and let us consider, at least in a brief excursus, a more pleasant topic - the issue of happiness in Pyrrho.

\section{Happiness}

Let us consider the question of how the radical denial of the possibility of knowing anything corresponds with the achievement of happiness promised by Pyrrho. If our philosopher disavows knowledge in general, he must disavow knowledge of values as well, i.e. knowledge of which values should determine our decisions, refusals, choices and actions. Can a human being who does not have knowledge of values achieve happiness? Pyrrho's affirmative answer may sound surprising or even shocking from a "human" viewpoint, ${ }^{22}$ but it results directly from the stance expressed in the following fragments:

disciplines (BRUNSCHWIG, J. Introduction..., p. 249; BURNYEAT, M. Tranquillity..., p. 91). This opinion was adopted by many in Antiquity as well. Cf. Cicero, who says of Pyrrho: "[...] (scil. Pyrrho) having posited virtue he leaves nothing as an object of desire whatever. [...] for the effect of their (scil. Pyrrho's and Aristo's) wish to make virtue on its own so allembracing was to rob virtue of the capacity to select things, and to grant it nothing either as its source or its foundation; consequently they undermined the very virtue which they embraced"; translation by Long - Sedley (LONG, A. - SEDLEY, D. The Hellenistic Philosophers II..., p. 19 ([...] qui [scil. Pyrrho] virtute constituta nihil omnino, quod appetendum sit, relinquat [...] dum enim in una virtute sic omnia esse voluerunt [scil. Pyrrho et Aristo], ut eam rerum selectione expoliarent nec ei quicquam, aut unde oriretur, darent, aut ubi niteretur, virtutem ipsam, quam amplexabantur, sustulerunt. De fin. IV,43,3-4, fr. 69C Caizzi; De fin. II,43,5-9, fr. 69B Caizzi).

22 It is this Pyrrhonian idea, i.e. that holding "no views" and "not deciding" leads to imperturbability and inner tranquility, that, according to several authors, constitutes an unparalleled element in Greece and in overall Greek philosophy (cf. BECKWITH, CH. Greek Buddha..., p. 18; BETT, R. Pyrrho, His Antecedents..., pp. 179 and 220). Only few of them plucked up the courage to look for its origins in the Eastern wisdom of ancient India (for bibliographical references, see footnote 5). 
The distress of the soul can be only avoided if we show to those who suffer from it because they want to avoid evil and chase after good that there is nothing which is either good or evil by nature, "but only among humans the convention ${ }^{23}$ sets thus

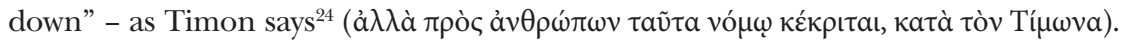

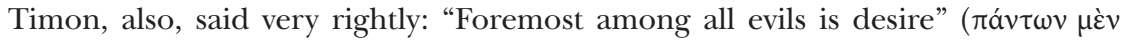

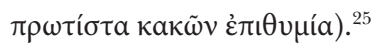

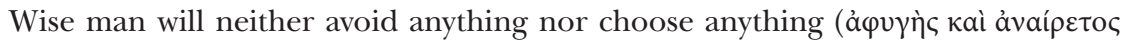

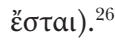

Consequently, the strongest enemies of inner tranquility - according to Pyrrho - are evaluating beliefs and judgements, which dictate what to choose and what to refuse, what to strive for and what to avoid, in our lives. Knowledge of good and evil is the greatest human illusion because this distinction is given by mere convention among people and does not have any substantial foundation. Nevertheless, choices based on the difference between good (desirable) and evil

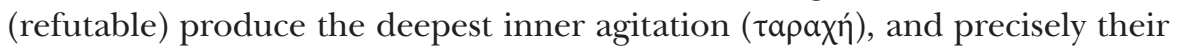
disavowal - which is, for Pyrrho, a part of the overall disavowal of knowledge itself - leads us, according to Pyrrho, first to speechlessness (ápa

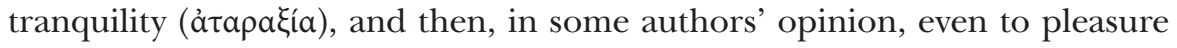

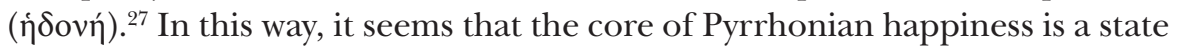
of lacking any motivation to make decisions and to perform actions of any sort - a state of speechlessness "blissful idleness". ${ }^{28}$ This attitude was viewed

23 Here, I accept Hirzel's emendation vó $\mu \omega$ for vów. This reading fits well with Diogenes Laer-

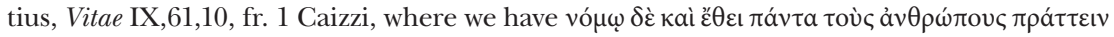
("custom and habit are the basis of everything that men do").

24 Sextus Empiricus, Adv. math. XI,140,1-6, fr. 64 Caizzi.

25 Athenaeus VIII,337 A, fr. 65 Caizzi. According to A. A. Long (LONG, A. - SEDLEY, D. The Hellenistic Philosophers II, 13), the hexameter verse was a part of Timon's 'Iv $\delta \alpha \lambda \mu o i ́(I m-$ ages), and Athenaeus probably found it in a gnomologium. On the historical authenticity of Timon's reproduction of Pyrrho's philosophy, see e.g., KALAŠ, A. Pyrrhón z Élidy..., pp. $108-111$.

26 Sextus Empiricus, Adv. math. XI,164,5, fr. 66 Caizzi.

27 Aristocles apud Eusebium, Praep. evang. XIV,18,4,2-4,3, fr. 53 Caizzi.

28 The possible Eastern provenience of this philosophical stance is hinted at in footnote 5 . 
less favorably by neo-Pyrrhonists, who attempted to re-interpret it, ${ }^{29}$ and to ancient non-skeptic authors, who engaged in criticizing it. ${ }^{30}$

\section{Self-Refutation}

Following this brief excursion into Pyrrho's "ethics without values", let us finally return to the issue of the self-refutation of his own assertions. How can Pyrrho be so sure that our beliefs and opinions, as well as our sensations, are neither true nor false if this claim itself entails disavowal of knowledge and thus makes the very assertion inadmissible? How can he proclaim, with such self-assuredness, propositions which claim to bear truth values while at the same time denying that our sensations and opinions have a share in the categories "true" and "false"?

The problem of Pyrrho's self-refutation is closely related to the radical denial of the possibility of knowledge that some scholars call negative dogmatism. ${ }^{31}$ We will see this more clearly when we further examine the meaning of negation in Pyrrho's mysterious, vigorously expressed claim about things in the world. According to Pyrrho, of every single thing we should assert, first, that "it no more is than is not", second, that "it no more is than both is and is not, and finally, that it no more is than neither is nor is not". I assume that for understanding the philosophical significance of these words, it is crucial to comprehend the meaning of the negation "no more" (ov $\mu \tilde{a} \lambda \lambda \mathrm{ov}$ ), which occurs several times in the sentence. If Pyrrho's dictum really bears deep epistemological validity, and if it means that no epistemological relevance can be assigned either to a simple sentence ("is") or to its negation

29 The neo-Pyrrhonian re-interpretation of Pyrrho consists in accepting "appearance" (tò

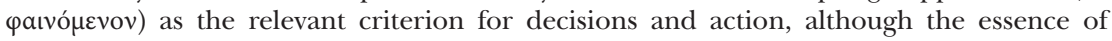
things always remains hidden for neo-Pyrrhonians and is practically irrelevant to attaining happiness. This so-called phenomenalistic interpretation of Pyrrho will also be attractive to certain modern authors, who will assign to him - anachronistically, let us note - precisely these neo-Pyrrhonian views, while at the same time minimizing or completely denying the differences between Pyrrho and neo-Pyrrhonism (bibliographical references can be found in footnote 4). For more on the phenomenalistic interpretation, see in KALAŠ, A. Pyrrhón z Élidy..., pp. 121-126.

30 In Antiquity, criticism of Pyrrho's notion of happiness usually came from the Stoic ranks, especially Cicero: cf. Cicero, De fin. II,43,5-9, fr. 69B Caizzi; ibidem IV,43,1-5, fr. 69C Caizzi.

31 See footnote 21. 
("is not"), or to a compound sentence containing a simple sentence and its negation ("both is and is not") or to a negation of such a compound sentence ("neither is nor is not"), then the first negation in the expression "no more

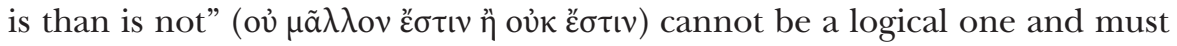
instead be a negation that we might call "epistemological". The meaning of the verb "is" ( thing about the existence or non-existence of an external thing (or things). The expression "is", in this case, is rather elliptical for "is something", "is of some specific kind", "is such and such". Negations such as "no more" in Pyrrho's famous sentence bear "epistemological" meaning because, I assume, when such a negation (or better, such a "denial", "refusal", or "rejection") is applied to any utterance, Pyrrho wants to say that that utterance - however complicated or even logically contradictory it may be - has absolutely no epistemological relevance. This is the needed "epistemological" negation, which has no logical dimension and which therefore does not change the meaning of the negated statement to its logical opposite, but rather refutes it, or "negates" it, epistemologically. ${ }^{32}$

An interesting solution to Pyrrho's self-refutation has been offered by R. Bett, who shows that Pyrrho's assertion about the nature of things and about the epistemological character of our perceptions and beliefs is a specific statement - or better, a "meta-statement" - which is, according to Bett, "exempt from its own scope". ${ }^{33}$ Bett's reasons for holding this are threefold: (1) The term "things" ( $\pi \rho \alpha ́ \gamma \mu \alpha \tau \alpha)$, the nature of which Pyrrho declares to be unknowable, refers, according to the everyday ancient Greek usage, to common single objects and states in the world around us. Therefore - let us

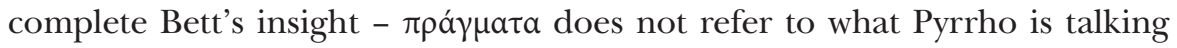
about when he makes apodictic assertions about things and the nature of

32 The fact that I am forging the term "epistemological negation" here does not mean that I prefer the epistemological interpretation of Pyrrho described above. By using the negation, Pyrrho simply denies the meaningfulness of each possible utterance without telling us why. R. Bett puts this succinctly, noting that "if they (scil. our opinions) were simply false, we could simply switch to a contrary set of opinions; but since they are neither true nor false (but purport to be true), we can avoid misconception only by avoiding opinions entirely" (BETT, R. Pyrrho, His Antecedents..., p. 30). A different opinion, based on the assumption that Pyrrho admitted the distinction between true and false, has been expressed by M. R. Stopper, in line with his favorite epistemological interpretation: "I think that Timon means not that 'our senses never tell the truth and never lie', but rather that 'our senses are neither constant truth-tellers nor constant liars'” (STOPPER, M. Schizzi.., p. 292, footnote 53).

33 BETT, R. Pyrrho, His Antecedents..., p. 24. 
our perceptions and beliefs. (2) Apparently, Pyrrho's "dogmatic" dicta are not derived from our perceptions (aỉ $\theta \dot{\sigma} \sigma \varepsilon ı \varsigma$ ), so it cannot be inferred of them that they are neither true nor false. (3) Pyrrho's key claims cannot be included in the realm of beliefs and opinions ( $\delta$ ó $\xi a \iota)$ either, which, in Pyrrho's view, have no epistemic relevance (ibidem, p. 24).

All three of Bett's arguments apparently attempt to vindicate, within Pyrrho's doctrine, the special status of Pyrrho's assertions about the unknowable nature of things and the epistemic value (or better, the "non-value") of statements acquired by means of reason and the senses. However, these arguments (especially the first) appear overly complicated and philosophically speculative, which apparently runs against Pyrrho's taste for straightforward and basic solutions. Particularly questionable is Bett's speculative assumption that Pyrrho had an exact understanding of the semantic range of the concept "things" ( $\pi \rho \alpha ́ \gamma \mu \alpha \tau \alpha)$, such that his apodictic statements about things and the nature of our perceptions and beliefs could be excluded by Pyrrho from the above semantic range of "things" ( $\left.\pi \rho \alpha \gamma_{\mu} \mu \tau \alpha\right)$. If I have Bett's reasoning right, it is precisely this exclusion of Pyrrho's key skeptic statements from the realm of "things" ( $\pi \rho \alpha ́ \gamma \mu \alpha \tau \alpha)$ - which, let us recall, are indifferentiable

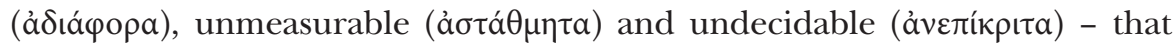
guarantees their real epistemic validity.

At this point, I would like to offer my own solution to the problem of self-refutation in Pyrrho. Like Bett, I am convinced that Pyrrho considered his key statements about the fundamental unknowability of the world to be excluded from the realm of common opinions ( $\delta$ ó $\xi \alpha)$. However, I would like to emphasize that he understood his "philosophical discovery" as a species of superhuman, divine wisdom which he himself had achieved and which was later glorified by his disciple Timon. In Sextus Empiricus, for instance, Timon says of his worshiped teacher that as a right criterion, Pyrrho had applied the word of truth. At the same time, he attributes to Pyrrho the claim that the nature of the divine and the good is the firm fundament for the most just life of man. ${ }^{34}$ Timon adored Pyrrho because he had managed to set himself free from the enslavement of people's opinions, ${ }^{35}$ and he elsewhere recounts

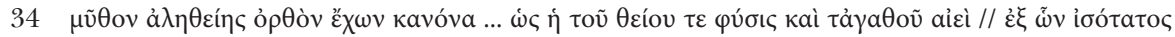

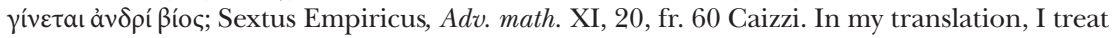
the phrase ỏ $\rho \theta \dot{o} v$ кavóva as a predicate to $\mu \tilde{v} \theta$ ov ả $\lambda \eta \theta \varepsilon i ́ n \varsigma$. For a different interpretation and translation of the line, see LONG, A. - SEDLEY, D. The Hellenistic Philosophers II, 19.

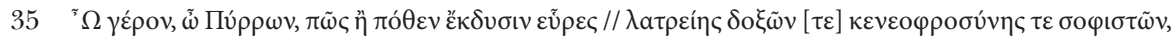

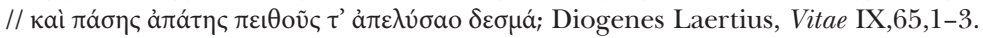


his divine way of life, which made him similar to the sun god. ${ }^{36}$ The divine truth, prophetically announced by the great philosopher Pyrrho as a messianic message ${ }^{37}$ directed (perhaps) to all humankind, thus achieves the status of a specific statement that is exempt from the sphere of its own autodestructing self-reference. Pyrrho's prophetic statements, being virtually the statements of a god, have every right to refute the epistemological relevance of statements about the things of the world because these refer only to human knowledge, not divine knowledge, which he possesses. In a certain sense, I consider my solution a development of the second and third points of Bett's suggestion (see above), pointing out that the different quality of Pyrrho's key declarations in comparison with other (mostly human) opinions and views ( $\delta$ ó al $_{\text {) }}$

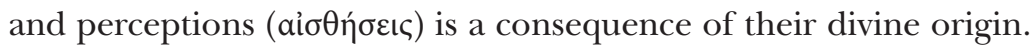

According to my interpretation, Pyrrho tries, in a majestic way, to announce a kind of divine truth to us, which produces an intellectual astonishment, a religious ecstasy, that cannot be subject to any (self-)refuting questioning. It seems very likely that in his answers to the three questions concerning the happy life, our philosopher wants to communicate at least a part of his divine

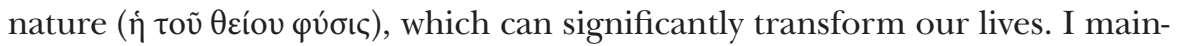
tain that one of the most cogent arguments in support of the "prophetic" character of Pyrrho's statements ${ }^{38}$ is the fact that he uses a specific stylistic figure: asyndeton. In addition, it shows that Pyrrho was not only a profound thinker, but also an outstanding man of letters and an adept stylist. ${ }^{39}$

I shall proceed with a short excursion into the theory of ancient Greek stylistics. In Greek, a series of multiple equivalent elements (sentences, attributes, predicates, etc.) can be linked together either by polysyndeton ${ }^{40}$ or

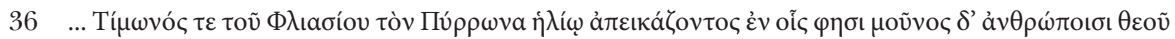

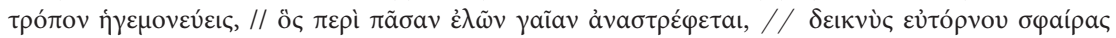

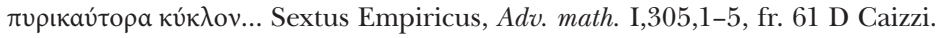

37 See especially Timon's conviction that Pyrrho "has broken shackles of every illusion of

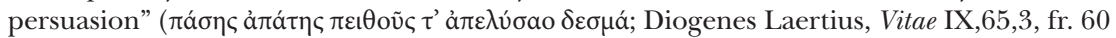
Caizzi).

38 In Antiquity, the proposed thesis finds particular support in Timon's declarations, quoted above.

39 One might rightfully ask why I think it is legitimate to put so much stress on the use of stylistic and rhetorical devices when it comes to a philosopher who is thought to have never written anything. I maintain that the use of stylistic figures described below was not limited, in Pyrrho's time, to written texts. The ancient Greeks, especially of the Classical era, appreciated spoken language much more than we do today.

SMYTH, H. Greek Grammar..., § 3043 . 
by asyndeton ${ }^{41}$ In short, polysyndeton is the multiple repetition of a connective, e.g. the conjunction "and" (кaí) in the sentence "Those who came were Michael and John and James and Frank". Asyndeton is defined by Smyth as follows: "Two or more sentences (or words) independent in form and thought, but juxtaposed, i.e. coordinated without any connective, are asyndetic ... and such absence of connectives is called asyndeton." ${ }^{42}$ Let us use as an example of asyndeton the same sentence, but without connective words: "Those who came were Michael, John, James, Frank." In fact, in the text by Pyrrho analyzed above concerning what should and should not be said about things, we do encounter asyndeton, an enumeration of alternative assertions about the world without connectives:

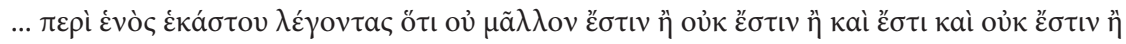

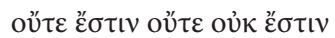

We should say of every single thing that it no more is [...] than [anaphora] is not, [...] [asyndeton] than [anaphora] both is and is not, [...] [asyndeton] than [anaphora] neither is nor is not. ${ }^{43}$

I maintain that Pyrrho used asyndeton deliberately and that it had a philosophical function. Incidentally, the text also includes anaphora, which is a device typically used along with asyndeton. ${ }^{44}$ The anaphora consists of the thrice-recurring comparative particle $\ddot{\eta}$ (= "than"), which in our text introduces (but does not connect, in which case it would be a polysyndeton) various alternatives of utterances about the world that are - according to the definition of asyndeton - independent and equivalent. ${ }^{45}$ The graphically modified text above makes clear that it contains at least two asyndeta and three anaphorae. The text is an instance of so-called rhetorical asyndeton, ${ }^{46}$

41 Ibidem, § 1033, §§ 2165-2167, § 3016.

42 Ibidem, § 2165.

43 Aristocles apud Eusebium, Praep. evang. XIV,18,3,5-4,1, fr. 53 Caizzi. A more explicit translation which fills in the elliptic gaps in the Greek text runs as follows: "We should say of every single thing that it no more is than is not, [...] that it no more is than both is and is not, $[\ldots]$ that it no more is than neither is nor is not." This version may be more reader friendly, but it is not very convenient for a philological and stylistic analysis of the original text.

44 SMYTH, H. Greek Grammar..., § 2167c.

45 See Smyth's definition of asyndeton in footnote 41.

46 SMYTH, H. Greek Grammar..., § 2165a. 
which has philosophical significance. Pyrrho knowingly expressed the emotive charge, vividness and impressiveness of his "philosophical discovery", namely the announced superhuman truth with a divine dimension. The emotiveness of this rhetorical asyndeton is even emphasized by the abovementioned anaphora. ${ }^{47}$ The emotional engagement is very likely identical to the intellectual astonishment which in Pyrrho results in religious awe and is closely related to the specific status of the "higher" truths communicated by him. Pyrrho's wisdom must have sounded like a majestic rhetorical symphony to the ancient Greek audience, a magnificent "Ode to Joy" announced to all.

\section{Conclusion}

In this paper, I have examined Pyrrho of Elis's specific, even agnostic, attitude toward the problem of truth. For Pyrrho, there is no truth that can be grasped by humans. The reason for this is not our inability to comprehend truth, but rather the very nature of things, which does not allow it. I have indicated how, according to Pyrrho, someone who is epistemologically and axiologically "emptied" can achieve happiness. I have also tried to address the issue of Pyrrho's self-refuting skepticism and have offered an elegant solution, identifying the rhetorical asyndeton and anaphora in Pyrrho's text. These rhetorical devices convey the status of specific utterances to Pyrrho's words - the status of "divine" (revealed) truths, which are exempt from the range of self-destructing auto-reference. If our inferences are correct, then Pyrrho shines forth on the horizon of Greek thought not only as an original thinker but as an outstanding orator. Taking into account his philosophy, we might wonder whether, with the exception, perhaps, of the worshippers of nirvana, his philosophical message might lead us to genuine happiness.

\section{References}

ANNAS, Julia. The Morality of Happiness. New York: Oxford University Press 1993. ATHENAEUS. Deipnosophistae. 3 vols. Edited G. Kaibel. Leipzig: Teubner 1887 (repr. 1966).

BECKWITH, Christopher. Greek Buddha. Pyrrho's Encounter with Early Buddhism in Central Asia. Princeton: Princeton University Press 2015.

47 Ibidem, § 2166. 
BETT, Richard. Pyrrho, His Antecedents, and His Legacy. Oxford: Oxford University Press 2000.

BRENNAN, Tad. Pyrrho on the Criterion. Ancient Philosophy. 1998, 18(2), pp. 417-433. BROCHARD, Victor. Les Sceptiques grecs. Paris: Imprimerie Nationale 1887.

BRUNSCHWIG, Jacques. Introduction: the Beginnings of Hellenistic Epistemology. In ALGRA, Keimpe - MANSFELD, Jaap - SCHOFIELD, Malcolm (eds.). The Cambridge History of Hellenistic Philosophy. Cambridge: Cambridge University Press 1999, pp. 220-259.

BURNYEAT, Myles Fredric. Tranquillity without a Stop: Timon, frag. 68. The Classical Quarterly. 1980, XXX (1), pp. 86-93.

CAIZZI, Decleva Fernanda. Pirrone. Testimonianze. Napoli: Bibliopolis 1981.

CAMPBELL, Lewis. V. Brochard, Les Sceptiques grecs, Paris, 1887 (review). The Classical Review. 1888, II (4), pp. 111-113.

CICERO, Marcus Tullius. De finibus bonorum et malorum. In SCHICHE, Theodor (ed.). M. Tulli Ciceronis scripta quae manserunt omnia, fasc. 43. Leipzig: Teubner 1915.

DIOGENES, Laertius. Vitae philosophorum. In LONG, Herbert S. (ed.). Diogenis Laertii vitae philosophorum, 2 vols. Oxford: Clarendon Press 1964, pp. 1-565.

EUSEBIUS, Caesarensis. Die Praeparatio evangelica. In MRAS, Karl (ed.). Eusebius Werke, VIII. Berlin: Akademie-Verlag 1954, pp. 3-613.

FRENKIAN, Aram M. Scepticismul grec i filozofia indiana. Bucuresti: Academia Republicii Socialiste Romania 1957.

FLINTOFF, Everard. Pyrrho and India. Phronesis. 1980, 25(1), pp. 88-108.

GÖRLER, Woldemar. Pyrrhon aus Elis. In FLASHAR, Hellmut (ed.). Grundriss der Geschichte der Philosophie. Die Philosophie der Antike, IV: Die Hellenistische Philosohie. Basel: Schwabe 1994, pp. 732-759.

HANKINSON, Robert J. The Sceptics. London: Routlege 1995.

HORYNA, Břetislav. Filosofie skepse. Olomouc: Nakladatelství Olomouc 2008.

KALAŠ, Andrej. Pyrrhón z Élidy alebo blažený život bez hodnôt. Bratislava: Univerzita Komenského v Bratislave 2009.

KUZMINSKI, Adrian. Pyrrhonism and the Madhyamaka. Philosophy East $\mathcal{E}$ West. 2007, 57 (4), pp. 482-511.

KUZMINSKI, Adrian. Pyrrhonism: how the ancient Greeks reinvented Buddhism. Lanham: Lexington Books 2008.

LONG, Anthony A. Hellenistic Philosophy. London: Duckworth 1974.

LONG, Anthony A. - SEDLEY, David N. The Hellenistic Philosophers, I-II. Cambridge: Cambridge University Press 1987.

SEXTUS, Empiricus. Adversus mathematicos. In MUTSCHMANN, Hermann - MAU, Jürgen. (eds.). Sexti Empirici opera, vols. 2, 3. Leipzig: Teubner 1961.

SEXTUS, Empiricus. Pyrrhoniae hypotyposes. In MUTSCHMANN, Hermann (ed.). Sexti Empirici opera, vol. 1. Leipzig: Teubner 1912, pp. 3-209.

SMYTH, Herbert W. Greek Grammar. Harvard: Messing 1957.

STOPPER M., R. Schizzi Pirroniani. Phronesis. 1983, 28(3), pp. 265-297.

STOUGH, Charlotte L. Greek Scepticism. Berkeley and Los Angeles: University of California Press 1969.

SVAVARSSON, Svavar Hrafn. Pyrrho's Undecidable Nature. In Oxford Studies in Ancient Philosophy 2004, 27, pp. 249-295. 
The Problem of Truth, Happiness and Self-Refutation in the Philosophical Viewpoint of the World ...

ZELLER, Eduard. Die Philosophie der Griechen in ihrer geschichtlichen Entwicklung. Leipzig: O. R. Reisland 1922.

\section{doc. Andrej Kalaš, PhD.}

Department of Philosophy and History of Philosophy, Faculty of Arts, Comenius University in Bratislava

Šafárikovo nám. 6, 81499 Bratislava, Slovak Republic andrej.kalas@uniba.sk 